\title{
Front Matter: Volume 8927
}

, "Front Matter: Volume 8927," Proc. SPIE 8927, Endoscopic Microscopy IX; and Optical Techniques in Pulmonary Medicine, 892701 (18 March 2014); doi: $10.1117 / 12.2053574$

SPIE. Event: SPIE BiOS, 2014, San Francisco, California, United States 


\title{
PROGRESS IN BIOMEDICAL OPTICS AND IMAGING
}

\section{Endoscopic Microscopy IX; and Optical Techniques in Pulmonary Medicine}

\author{
Guillermo J. Tearney \\ Thomas D. Wang \\ Melissa J. Suter \\ Stephen Lam \\ Matthew Brenner \\ Editors
}

1-3 February 2014

San Francisco, California, United States

Sponsored and Published by

SPIE 
The papers included in this volume were part of the technical conference cited on the cover and title page. Papers were selected and subject to review by the editors and conference program committee. Some conference presentations may not be available for publication. The papers published in these proceedings reflect the work and thoughts of the authors and are published herein as submitted. The publisher is not responsible for the validity of the information or for any outcomes resulting from reliance thereon.

Please use the following format to cite material from this book:

Author(s), "Title of Paper," in Endoscopic Microscopy IX; and Optical Techniques in Pulmonary Medicine, edited by Guillermo J. Tearney, Thomas D. Wang, Melissa J. Suter, Stephen Lam, Matthew Brenner, Proceedings of SPIE Vol. 8927 (SPIE, Bellingham, WA, 2014) Article CID Number.

ISSN: 1605-7422

ISBN: 9780819498403

Published by

SPIE

P.O. Box 10, Bellingham, Washington 98227-0010 USA

Telephone +1 3606763290 (Pacific Time) · Fax +1 3606471445

SPIE.org

Copyright (C) 2014, Society of Photo-Optical Instrumentation Engineers.

Copying of material in this book for internal or personal use, or for the internal or personal use of specific clients, beyond the fair use provisions granted by the U.S. Copyright Law is authorized by SPIE subject to payment of copying fees. The Transactional Reporting Service base fee for this volume is $\$ 18.00$ per article (or portion thereof), which should be paid directly to the Copyright Clearance Center (CCC), 222 Rosewood Drive, Danvers, MA 01923. Payment may also be made electronically through CCC Online at copyright.com. Other copying for republication, resale, advertising or promotion, or any form of systematic or multiple reproduction of any material in this book is prohibited except with permission in writing from the publisher. The CCC fee code is $1605-7422 / 14 / \$ 18.00$.

Printed in the United States of America.

Publication of record for individual papers is online in the SPIE Digital Library.

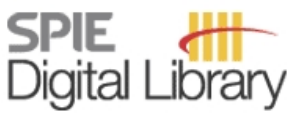

SPIEDigitalLibrary.org

Paper Numbering: Proceedings of SPIE follow an e-First publication model, with papers published first online and then in print and on CD-ROM. Papers are published as they are submitted and meet publication criteria. A unique, consistent, permanent citation identifier (CID) number is assigned to each article at the time of the first publication. Utilization of CIDs allows articles to be fully citable as soon as they are published online, and connects the same identifier to all online, print, and electronic versions of the publication. SPIE uses a six-digit CID article numbering system in which:

- The first four digits correspond to the SPIE volume number.

- The last two digits indicate publication order within the volume using a Base 36 numbering system employing both numerals and letters. These two-number sets start with 00, 01, 02, 03, 04, $05,06,07,08,09,0 A, 0 B \ldots 0 Z$, followed by $10-1 Z, 20-2 Z$, etc. 


\section{Contents}

$\checkmark \quad$ Conference Committee

\section{Part A Endoscopic Microscopy IX}

\section{FLUORESCENCE/SPECTROSCOPY}

8927 OG Design of a rectal probe for diffuse optical spectroscopy imaging for chemotherapy and radiotherapy monitoring [8927-16]

M. van de Giessen, Leids Univ. Medical Ctr. (Netherlands) and Delft Univ. of Technology (Netherlands); Y. Santoro, S. Mirzaei Zarandi, Beckman Laser Institute (United States); A. Pigazzi, Univ. of California, Irvine (United States); A. E. Cerussi, B. J. Tromberg, Beckman Laser Institute (United States)

8927 Ol Multi-spectral scanning fiber endoscope with concurrent autofluorescence mitigation for enhanced target-to-background ratio imaging [8927-18]

C. Yang, V. W. Hou, L. Y. Nelson, R. S. Johnston, C. D. Melville, E. J. Seibel, Univ. of

Washington (United States)

\section{ADVANCED MICROSCOPY II}

8927 OR Volume holographic reflection endoscope for in-vivo ovarian cancer clinical studies [8927-28]

I. D. Howlett, College of Optical Sciences, The Univ. of Arizona (United States); M. Gordon, J. W. Brownlee, College of Optical Sciences, The Univ. of Arizona (United States);

J. K. Barton, College of Optical Sciences, The Univ. of Arizona (United States) and The Univ. of Arizona (United States); R. K. Kostuk, College of Optical Sciences, The Univ. of Arizona (United States)

8927 OT Ultrahigh speed endoscopic swept source optical coherence tomography using a VCSEL light source and micromotor catheter [8927-30]

T.-H. Tsai, O. O. Ahsen, H.-C. Lee, K. Liang, M. G. Giacomelli, Massachusetts Institute of Technology (United States); B. M. Potsaid, Massachusetts Institute of Technology (United States) and Thorlabs, Inc. (United States); Y. K. Tao, Massachusetts Institute of Technology (United States); V. Jayaraman, Praevium Research, Inc. (United States); M. F. Kraus, Massachusetts Institute of Technology (United States) and Friedrich-Alexander-Univ. Erlangen-Nürnberg (Germany); J. Hornegger, Friedrich-Alexander-Univ. Erlangen-Nürnberg (Germany); M. Figueiredo, Q. Huang, H. Mashimo, VA Boston Healthcare System (United States) and Harvard Medical School (United States); A. E. Cable, Thorlabs Inc. (United States); J. G. Fujimoto, Massachusetts Institute of Technology (United States) 


\title{
Part B Optical Techniques in Pulmonary Medicine
}

\author{
CLINICAL I
}

$89270 Z$ Sex differences in chronic obstructive pulmonary disease evaluated using optical coherence tomography [8927-37]

M. Kirby, The Univ. of British Columbia (Canada) and St. Paul's Hospital (Canada);

W. Zhang, The BC Cancer Agency Research Ctr. (Canada); P. K. Laratta, The Univ. of British Columbia (Canada); D. D. Sin, St. Paul's Hospital (Canada); S. Lam, The BC Cancer Agency Research Ctr. (Canada); H. O. Coxson, The Univ. of British Columbia (Canada)

and St. Paul's Hospital (Canada)

\section{NOVEL ASSESSMENT AND TREATMENT TECHNIQUES}

8927 1A Photodynamic inactivation of microorganisms which cause pulmonary diseases with infrared light: an in vitro study [8927-48]

I. S. Leite, Univ. de São Paulo (Brazil); M. C. Geralde, Univ. Federal de São Carlos (Brazil); A. C. Salina, A. I. Medeiros, Univ. Estadual Paulista (Brazil); C. Kurachi, V. S. Bagnato, N. M. Inada, Univ. de São Paulo (Brazil)

8927 1B Pulmonary decontamination for photodynamic inactivation with extracorporeal illumination [8927-49]

M. C. Geralde, Univ. de São Paulo (Brazil) and Univ. Federal de São Carlos (Brazill; I. S. Leite, N. M. Inada, C. Grecco, Univ. de São Paulo (Brazil); A. I. Medeiros, Univ. Estadual Paulista (Brazil); C. Kurachi, V. S. Bagnato, Univ. de São Paulo (Brazil)

8927 ID Automated segmentation of porcine airway wall layers using optical coherence tomography: comparison with manual segmentation and histology [8927-51]

M. Kirby, The Univ. of British Columbia (Canada) and St. Paul's Hospital (Canada); A. M. D. Lee, The BC Cancer Agency Research Ctr. (Canada); T. Candido, The Univ. of British Columbia (Canada); C. MacAulay, P. Lane, S. Lam, The BC Cancer Agency Research Ctr. (Canada); H. O. Coxson, The Univ. of British Columbia (Canada) and St. Paul's Hospital (Canada)

Author Index

iv 


\title{
Conference Committee
}

\author{
Symposium Chairs
}

James G. Fujimoto, Massachusetts Institute of Technology

(United States)

R. Rox Anderson, Wellman Center for Photomedicine, Massachusetts General Hospital (United States) and Harvard School of Medicine (United States)

Program Track Chair

Brian Jet-Fei Wong, Beckman Laser Institute and Medical Clinic (United States)

\section{Part A Endoscopic Microscopy IX}

\section{Conference Chairs}

Guillermo J. Tearney, Wellman Center for Photomedicine (United States)

Thomas D. Wang, University of Michigan (United States)

\section{Conference Program Committee}

David L. Dickensheets, Montana State University (United States)

Arthur F. Gmitro, The University of Arizona (United States)

Ralf Kiesslich M.D., Johannes Gutenberg Universität Mainz (Germany)

Francois Lacombe, Mauna Kea Technologies (France)

Stephen Lam, The BC Cancer Agency Research Center (Canada)

Hiroshi Mashimo, VA Boston Healthcare System (United States)

Kenzi Murakami, Olympus Corporation (Japan)

Norman S. Nishioka M.D., Massachusetts General Hospital

(United States)

Wibool Piyawattanametha, National Electronics and Computer

Technology Center (Thailand)

Mark J. Schnitzer, Stanford University School of Medicine

(United States)

Peter T. C. So, Massachusetts Institute of Technology (United States)

Melissa J. Suter, Massachusetts General Hospital (United States) 
Session Chairs

1 Spectral Encoding I

Dvir Yelin, Technion-Israel Institute of Technology (Israel)

2 Advanced Microscopy I

Thomas D. Wang, University of Michigan (United States)

3 OCT Probes

Xingde Li, Johns Hopkins University (United States)

4 Fluorescence/Spectroscopy

Thomas D. Wang, University of Michigan (United States)

5 Spectral Encoding II

DongKyun Kang, Massachusetts General Hospital (United States)

6 Multiphoton Microscopy

Peter T. C. So, Massachusetts Institute of Technology (United States)

7 Advanced Microscopy II

Andrew R. Rouse, The University of Arizona (United States)

8 Miniature Instruments for Endoscopic Microscopy: Joint Session with Conferences 8927A and 8977

Jonathan T. Liu, Stony Brook University (United States)

\section{Part B Optical Techniques in Pulmonary Medicine}

Conference Chairs

Melissa J. Suter, Massachusetts General Hospital (United States)

Stephen Lam, The BC Cancer Agency Research Center (Canada)

Matthew Brenner, University of California, Irvine (United States)

Conference Program Committee

Johannes de Boer, Vrije Universiteit Amsterdam (Netherlands)

Edmund Koch, Universitätsklinikum Carl Gustav Carus Dresden

(Germany)

David D. Sampson, The University of Western Australia (Australia)

Luc Thiberville, Hôpitaux de Rouen (France)

Victor X. D. Yang, Ryerson University (Canada)

Septimiu D. Murgu M.D., The University of Chicago (United States)

Robert A. McLaughlin, The University of Western Australia (Australia) 
Session Chairs

9 Clinical I

Stephen Lam, The BC Cancer Agency Research Center (Canada)

10 Animal Models

Matthew Brenner, University of California, Irvine (United States)

11 Mucus and Cilia

Robert A. McLaughlin, The University of Western Australia (Australia)

12 Novel Assessment and Treatment Techniques

Melissa J. Suter, Massachusetts General Hospital (United States)

13 Clinical II

Lida Hariri, Massachusetts General Hospital (United States)

Melissa J. Suter, Massachusetts General Hospital (United States) 
Proc. of SPIE Vol. $8927892701-8$

Downloaded From: https://www.spiedigitallibrary.org/conference-proceedings-of-spie on 26 Apr 2023 Terms of Use: https://www.spiedigitallibrary.org/terms-of-use 